\title{
Gender, Labor, and Geography \\ Mapping the Economic Life Cycles of German-born and Irish-born Immigrants in 1880 New York City
}

Senior thesis submitted in partial fulfillment of the requirements for the Bachelor of Arts degree with a major in Information Science and History

By Celia Levenstein Arsen

Barnard College, Columbia University

Advisor, Professor Alan Dye

April 27, 2020 


\section{TABLE OF CONTENTS}

List of Tables and Figures...........................................................................................ii

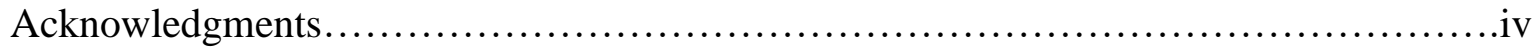

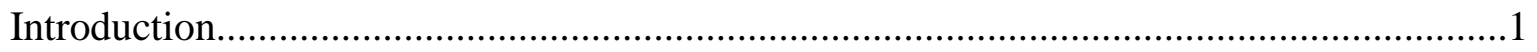

Relevant Literature and Question Formation.........................................1

Part 1: Gender-Based Occupational Segregation and Gendered

Residential Patterns.........................................................................

Data Sources.............................................................

Layout of 1880 New York City.............................................

Gender-based Occupational Segregation.....................................19

Spatial Implications of Gender-based Occupational Segregation..................24

Our Archetypes: The Irish Bridget and the German Seamstress ..................29

Inclusion and Exclusion in Domestic Service....................................31

Gender-Based Division of Labor Within Occupations...............................................34

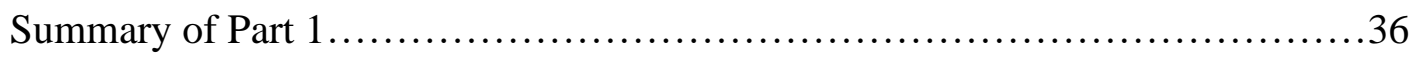

Part 2: The Economic Life Cycle of Women in 1880 New York City...................37

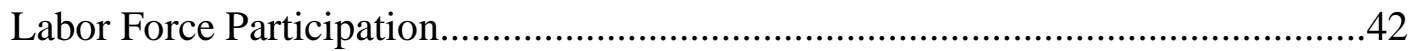

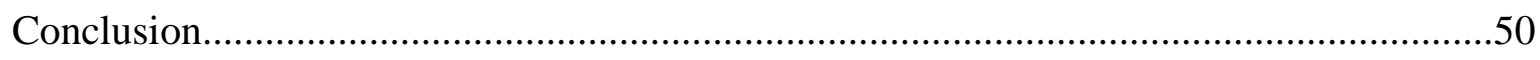

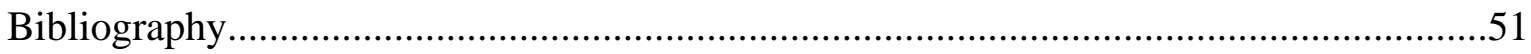




\section{LIST OF TABLES}

Table 1. Top Ten Occupations in 1880 New York City by Gender..........................18

Table 2. Top Ten Occupations of German-born Immigrants in New York City,

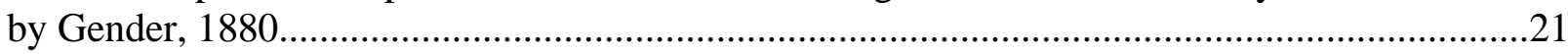

Table 3. Top Ten Occupations of Irish-born Immigrants in New York City,

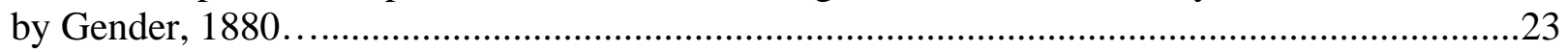

Table 4. Marital and Parental Status of Employed Women, by Ethnicity.....................39

Table 5. Female Labor Force Participation Rate by Age, Ethnicity, and Marital Status.........43

Table 6. Female Labor Force Participation Rate by Age, Ethnicity, and Parental Status.........46

\section{LIST OF FIGURES}

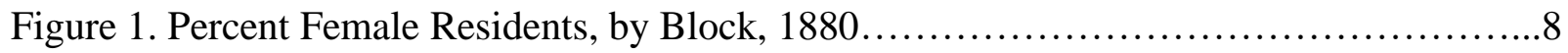

Figure 2. Number of Female Domestic Servants Per Acre, by Block, 1880..................10

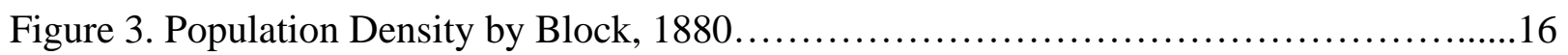

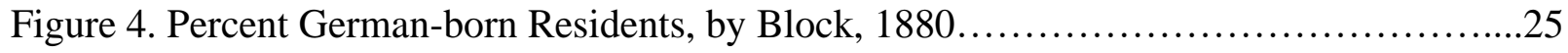

Figure 5. German-born Residents by Gender and Employment Status, 1880................27

Figure 6. Irish-born Residents by Gender and Employment Status, 1880..................28

Figure 7. Gendered Division of Labor in Book Manufacturing ...........................35

Figure 8. Irish-born Residents by Marital, Parental, Employment Status, and Gender, 1880. 


\section{ACKNOWLEDGEMENTS}

I completed this project with the help and guidance of many people. I would like to thank:

Professor Alan Dye, my thesis advisor, for your thoughtful and steadfast advice.

Professor Gergely Baics, my academic advisor, for sparking my interest in mapping nineteenth century New York City. I could not be more grateful for your unwavering support throughout my academic career at Barnard.

My mentors, coworkers, and friends at the Barnard Empirical Reasoning Center for teaching me the technical skills I needed to complete this project, and for creating a space where it was cool to geek out about data analysis - especially maps of women.

The members of the Historical Geography and GIS Network at the 2019 Social Science History Association Meeting for helpful feedback.

My roommates, who provided the encouragement I needed to pursue a technical degree. I could not have completed my curriculum without your academic and emotional support.

My incredible friends, both in New York City and in Ann Arbor who have heard me talk more about maps than was ever welcome.

My parents, for teaching me how to ask questions and think an economist, but not too much.

Emily, for being a great big sister. 


\section{DEDICATED}

to the women working on the frontlines in New York City in the midst of the COVID-19 crisis.

It is apparent now more than ever that women's work is the lifeblood of this city. 
This thesis examines the relationship between gender-based occupational segregation and gender-based residential patterns. Specifically, I find that Irish-born immigrants were more likely to be employed in highly gender-segregated occupations than their German-born counterparts. This had a spatial impact on the residential patterns of Irish-born men and women. Because Irishborn immigrants tended to work in highly gender-segregated occupations that were located in different parts of the city, Irish-born men and women disproportionately lived in different areas. I discuss some of the historical and contextual factors that explain why Irish-born women were more likely than German-born women to go into highly gender-segregated occupations. Lastly, I show how this relationship between occupational segregation and geography impacted the economic life cycles of these immigrant women. In particular, I identify how likely women were to leave the workforce after getting married or having children.

Geography helps us understand the economic life cycle of first-generation immigrant women in 1880 New York City. Ultimately, this tells a story about the gendered geographies of working immigrant women in the largest American city during the Gilded Age.

\section{Relevant Literature and Question Formation}

Women's participation and role in the paid labor force is important because it is deeply tied to female independence and autonomy. When American women enter the workforce, they not only gain social power within their families, but political power within their communities. Previous studies have established this concept, and have measured female labor force participation and the role of women in the labor force throughout American history. ${ }^{1}$ Claudia 
Goldin, in her seminal book, Understanding the Gender Gap, completes a thorough analysis of female labor force participation from 1790 to 1988 in the U.S. ${ }^{2}$ Not only does she track female labor force participation throughout two centuries, she also identifies cohorts of women, allowing her to estimate when women left and entered the workforce around important life events, namely marriage and motherhood. While a very thorough analysis, an element that Goldin does not include in her study, and that most traditional studies of female labor do not incorporate, is geography.

I posit that geography is one of the key elements that impacts when and why women enter and leave the workforce. I am not the first to sustain this argument. In their book Gender, Work, and Space, Geraldine Pratt and Susan Hanson argue that social and economic geographies are the means by which women have been historically segregated into poorly paid jobs. ${ }^{3}$ Their book is an in-depth study of Worcester, Massachusetts in the 1970s and 1980s. The study is largely concerned with gendered differences in home to work commutes and the inequalities those produce between working men and women. ${ }^{4}$ Their research presents a wealth of useful methods for investigating the intersection of gender, work, and space, but their methods are not easily reproducible for historical analysis.

Pratt and Hanson's analysis relies heavily on having both the home and work addresses of individuals. While historical censuses provide the residential addresses of American individuals,

2. Claudia Goldin, Understanding the Gender Gap: An Economic History of American Women (Oxford, England: Oxford University Press, 1990), 10-55.

3 Susan Hanson and Geraldine Pratt, Gender, Work, and Space (London and New York: Routledge, 1995).

4. It has been repeatedly shown in contemporary studies that women work closer to home than men do, and a variety of competing theories explain why this is the case. See: Hanson and Pratt, Gender, Work and Space; Janice Madden, "Why Women Work Closer to Home," Urban Studies 18 no. 2 (June 1981): 181-94; Roberto M. Fernandez and Celina Su, "Space in the Study of Labor Markets," Annual Review of Sociology 30, no. 1 (August 1, 2004): 545-69; Orna Blumen, "Gender Differences in the Journey to Work," Urban Geography 15, no. 3 (April 1, 1994): 223-45; Michelle J. White, "Sex Differences in Urban Commuting Patterns," The American Economic Review 76, no. 2 (1986): 368-72. 
the Census does not collect place of employment. Matching individual's residential addresses to their place of employment is a terribly messy feat. Researchers who wish to find working locations of nineteenth century residents must rely largely on city directories, which systematically exclude women. Typically, if the head of the household was a man, the women in the household would not be included in the city directory. If a woman was listed in the directory, it was still uncommon for their place of employment to be recorded. Currently, a complete study of the gendered geography of working women, that is, research that analyzes more than a small sample of the population, cannot realistically rely on place of employment data. In this thesis, I present methods for understanding the intersection of gender, work, and space that are effective for historical research, utilizing exclusively the Decennial Census.

While there are limitations to historical demographic data analysis, one benefit is that researchers can work on a granular, individual level scale without being concerned with violating the confidentiality of human subjects. The Common Rule limits human subject protections to living people. ${ }^{5}$ Because Pratt and Hanson conducted a contemporary study, they had to maintain the confidentiality of their human subjects and could only work with a sample of the population. In several instances, they admit that they could not draw precise conclusions because they had to aggregate their findings to sufficiently large geographic levels to protect the anonymity of their data sources, at the expense of precise findings. This is a common issue for geographers and social scientists who work with contemporary data. However historical data from 1880 do not need to be anonymized because the people are not alive. Feminist geographers have noted that

5. In paragraph (e)(1), section 46.102, Subpart A of The Common Rule a human subject is defined as "a living individual about whom an investigator (whether professional or student) [conducts] research..." 
when granular data are available, "GIS methods can be attentive to the diversity and differences among individuals," allowing us to connect geographical context and women's everyday lives. ${ }^{6}$

In her article, "Re-Focus on Women in an Industrial Revolution," Sherry Olson uses historical individual-level data to her advantage to investigate the geographies of working women in Montreal from 1848-1903. ${ }^{7}$ She finds that the gender and age composition of Montreal neighborhoods was greatly impacted by the presence of industries and institutions that depended on a gendered labor force. For example, neighborhoods with cotton mills had an overrepresentation of young women because of the presence of their overwhelmingly female employees. Upper middle-class neighborhoods were also disproportionately comprised of young women because they lived and worked in the homes of their wealthy employers as domestic servants.

What does this analysis look like in a nineteenth century American city? New York City in 1880 was evolving rapidly and bursting at the seams. From 1870 to 1880 the New York City population grew from 942,292 persons to over 1.2 million, a 28 percent increase. ${ }^{8}$ Furthermore, over 56 percent of people employed in 1880 New York City were foreign-born immigrants. ${ }^{9}$ While previous studies concerned with gender, geography, and labor have largely left race and ethnicity out of the equation, it is clear that a story about the 1880 New York City workforce cannot be told without considering the crucial role of immigrants. In this study I focus on

\footnotetext{
6. Mei-Po Kwan, "Feminist Visualization: Re-Envisioning GIS as a Method in Feminist Geographic Research," Annals of the Association of American Geographers, Association of American Geographers 92, no. 4 (December 1, 2002): 645-61.

7. Sherry Olson, "Re-Focus on Women in an Industrial Revolution," In The Routledge Companion to Spatial History, ed. Ian Gregory, Don DeBats, and Don Lafreniere (New York: Routlege), 12-34.

8. "Pop Culture: 1880," United States Census Bureau, accessed May 8, 2018, https://www.census.gov/history/www/through_the_decades/fast_facts/1880_fast_facts.html.

9. Unless explicitly cited otherwise, all figures in this thesis are drawn from the 1880 Decennial U.S. Census. Specifically, from IPUMS. Ruggles, Flood, Goeken, et. al., IPUMS USA: Version 9.0 [dataset] (Minneapolis, 2019).
} 
German-born and Irish-born immigrants, not only because these two groups of first-generation immigrants collectively made up over 40 percent of the entire New York City labor force, but because their women occupied different social and economic positions in the city, which allows for an interesting and illustrative comparison. Many existing qualitative studies document the lived experiences of German and Irish women in nineteenth century New York City. ${ }^{10}$ I build on these previous studies to tell a data-driven story about the labor force patterns and economic life cycles of Irish-born and German-born women in 1880 New York City, keeping in mind that geography is crucial to creating a comprehensive understanding of their story.

In Part 1, I examine occupational segregation to understand the gendered geographies of German-born and Irish-born immigrants. Ultimately, I find that Irish-born immigrants were more likely to work in highly gender-segregated occupations than German-born immigrants, and this had a visible impact on where men and women lived within the city. Next, I dig deeper into why Irish-born women were more likely than German-born women to go into highly gendersegregated occupations like domestic service. In Part 2, I tease out how the relationship between occupational segregation and geography impacted the economic life cycle of women in these two ethnic groups. Specifically, I identify how likely women were to leave the workforce after getting married or having children.

10. Christine Stansell, City of Women: Sex and Class in New York, 1789-1860 (Champaign, Illinois: University of Illinois Press, 1987); Rosalyn Baxandall, Linda Gordon, ed., America's Working Women: A Documentary History, 1600 to the Present (New York, W. W. Norton \& Company, 1995); Doris Weatherford, Foreign and Female: Immigrant Women in America, 1840-1930 (New York: Schocken Books, 1986); Milton Cantor and Bruce Laurie, ed., Class, Sex, and the Woman Worker (Westport, CT: Greenwood Press, 1977); Margaret E. Lynch-Brennan, The Irish Bridget: Irish Immigrant Women in Domestic Service in America, 1840-1930 (Syracuse, New York: Syracuse University Press, 2014); Faye Dudden, Serving Women: Household Service in Nineteenth-Century America (Middletown, CT: Wesleyan University Press, 1983). 


\section{Part 1: Gender-Based Occupational Segregation and Gendered Residential Patterns}


New York City in 1880 was growing rapidly, and as city life grew, the dynamics of the home also changed drastically, particularly for women. Prior to massive urbanization, young women were largely expected to live with their parents until marriage, to help at home, and to work on the farm. However, in the industrializing city this labor was not necessary, and more women began to enter the paid workforce. In general, mapping gender can be difficult because people do not typically cluster geographically by gender the way that they may by class or race. However, by mapping the percent of people on the city block that are women, as in Figure 1, the spatial variation in the concentration of women in 1880 New York City is apparent. Specifically, Midtown and parts of East Harlem are disproportionately female. On each city block, the percent female is calculated as the number of women on the block divided by the total number of people on the block. On average, a New York City block was 52 percent female. Figure 1 shows how many standard deviations each block was from the average of 52 percent female. The map shows that most blocks in Midtown were 0.5 standard deviations or more from the average percent female. 
Figure 1. Percent Female Residents, by Block, 1880

Standard Deviation Units Relative to New York City Mean

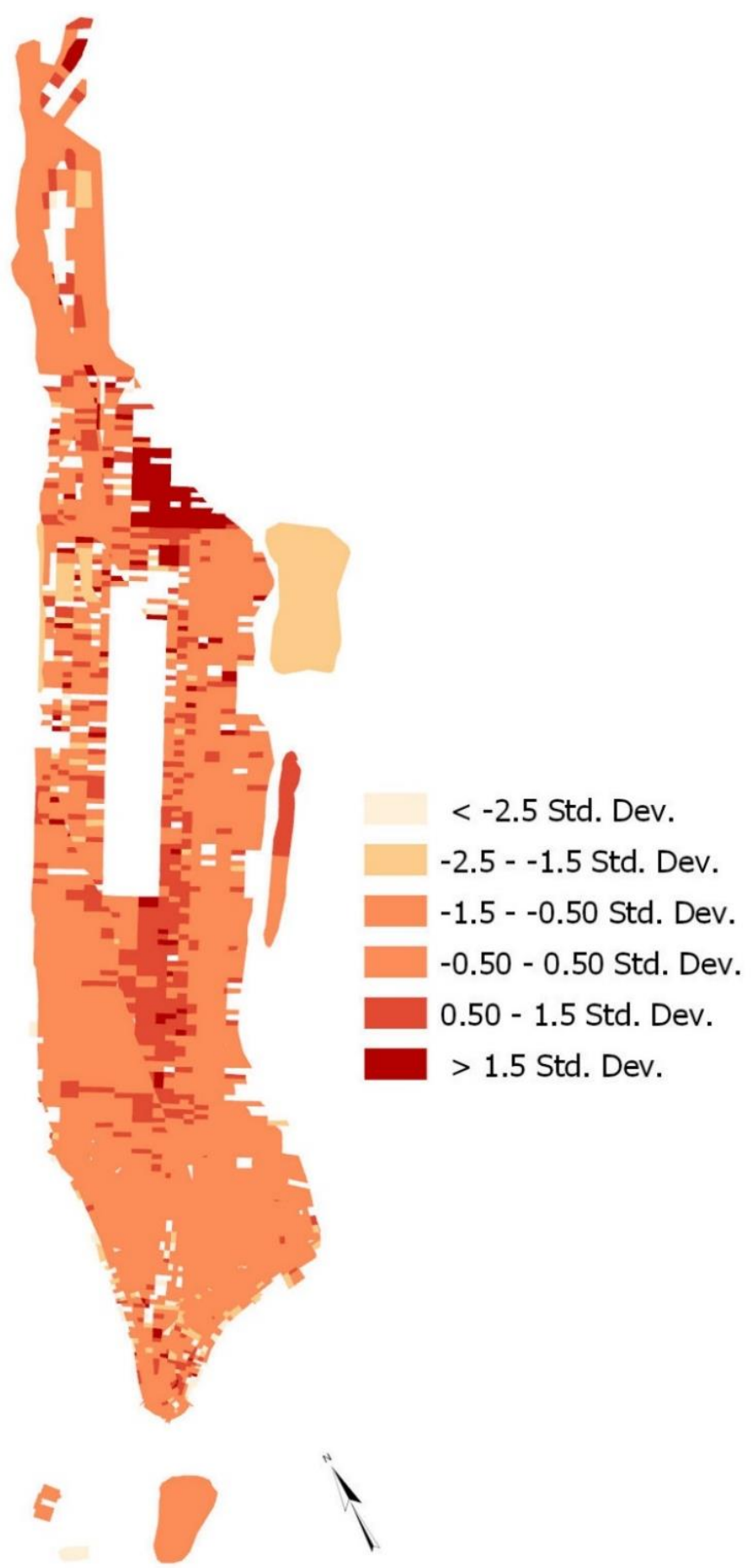

Source: Ruggles, Flood, Goeken, et. al., IPUMS USA: Version 9.0 [dataset] (Minneapolis, 2019). Note: Mean for New York City blocks is 52 percent. One standard deviation is 13 percentage points. 
The most immediate explanation we can give to this surprising spatial pattern is the presence of female domestic workers who worked and lived in Midtown. At the time, Midtown was an upper middle-class neighborhood, and female domestic servants lived in the homes of their wealthier employers. In 1880, domestic service was, by far, the most important occupation for American women. This was particularly the case in cities. In 1880, 15 percent of the U.S. population resided in the 50 largest cities, but a disproportionate 32 percent of all servants were employed in cities. ${ }^{11}$ Hiring a young woman to work in the home as a chambermaid, cook, child nurse, laundress, or waitress was common practice among middle-class families in urban centers. In Manhattan, 39 percent of all female wage earners were domestic servants. Therefore, understanding the lives of female domestic servants is a crucial component in understanding the changing gender and labor dynamics of the rapidly developing city in the Gilded Age.

Figure 2 maps the population density of female domestic workers, measuring the number of female domestic workers per acre on the block level. We see that female domestic servants were more densely populated in the parts of the city that were disproportionately female in Figure 1.

11. David Katzman, Seven Days a Week: Women and Domestic Service in Industrializing America (New York: Oxford University Press, 1978), 59. 
Figure 2. Number of Female Domestic Servants Per Acre, by Block, 1880

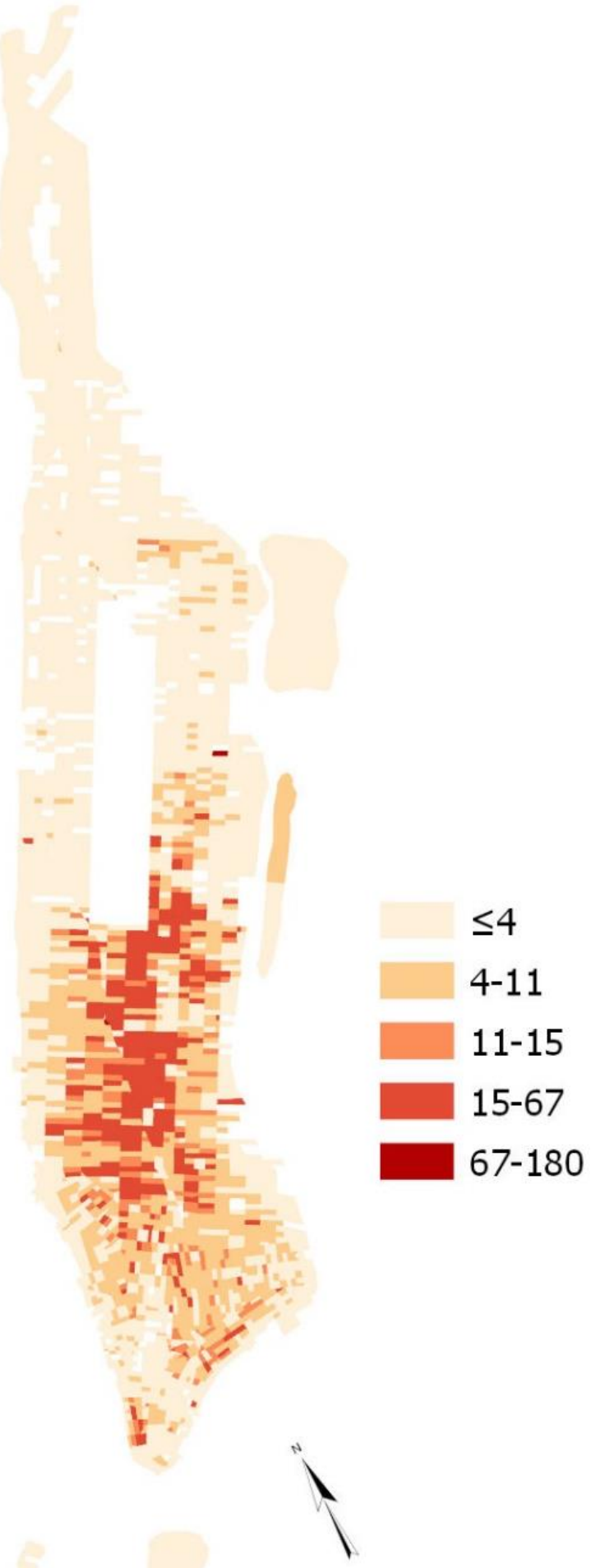

Source: Ruggles, Flood, Goeken, et. al., IPUMS USA: Version 9.0 [dataset] (Minneapolis, 2019). 
This tells us that understanding gender and space in 1880 New York City requires investigating labor as well. Ethnicity is also an important component of this calculation, considering that 44 percent of all domestic workers in New York City were Irish-born women. This study focuses on Irish-born and German-born immigrants, the two largest immigrant populations in the city. Not only did these two groups of first-generation immigrants collectively make up over 40 percent of the entire New York City labor force, but their women also occupied different social and economic positions in the city, which allows for an interesting and illustrative comparison. Namely, Irish-born women were more likely to work in domestic service than German-born women, and German-born women were more likely to work in cottage industries than Irish-born women. The following section discusses the data sources used to investigate these questions.

\section{Data Sources}

This project uses the full count of the 1880 U.S. Census from IPUMS. The Census provides useful information for this study because it collects the age, race, gender, birthplace, parental status, marital status, occupation, and home address of all residents in the U.S. The full counts, meaning the complete responses from every resident, are available for every decennial Census from 1850 to 1940 . The 1880 Census is particularly useful for spatial analysis because John Logan's Urban Historical GIS Project has geocoded the residential addresses of all 1880 Census respondents in 39 cities, including New York City. ${ }^{12}$ Geocoded addresses mean that with each Census response, we also have the exact latitudinal and longitudinal coordinate of their 
home address, which can be used for spatial analysis in a geographic information system (GIS). The geocoded Census data offer the opportunity for rigorous and granular spatial analysis of women in New York City. IPUMS's most recent release of the 1880 Census incorporates the latitudinal and longitudinal coordinates from John Logan's Urban Historical GIS Project. The incorporation of the geocoded coordinates with the Census data from IPUMS made this study possible, particularly when focusing on occupations. Instead of sifting through thousands of unique occupations that were hand-recorded by Census enumerators, all the residents in the dataset have been coded to one of the 286 occupations in the IPUMS 1880 occupational coding scheme. This made comprehensive analysis across multiple occupations feasible

Of course, there are also several limitations to these data. For research on working women, place of employment would be very useful information. Unfortunately, that is not collected in the Decennial Census. Currently, the most successful method for connecting residents to their place of employment in nineteenth century cities is by matching residents to their name in a city directory. In the 1880s, city directories often listed a resident's place of employment along with their name, but directories usually only listed the head of household, leaving women mostly anonymous. The Census provides a more complete understanding of where women worked, even though it lacks their employment location. With that said, thousands of respondents to the 1880 Census had no occupation recorded. It is important to note that those people with missing occupations were most likely disproportionately women. Nineteenth century social statisticians and suffragettes worried that there was an underrepresentation of female labor in the U.S. Census because male enumerators would assume that female respondents did not work, and would not ask female residents for their occupation. ${ }^{13}$ Additionally, researchers

13. Dudden, Serving Women, 74. 
worried that women did not self-report their occupation if it was casual, temporary, or parttime. ${ }^{14}$ Francis Amasa Walker, the 1880 Census superintendent cautiously allowed supervisors to hire female enumerators, stating that "in many regions such appointments would be highly objectionable; but the Supervisor [was] not prepared to say that localities [could] not be found where a canvass of the population by women could be conducted without any disadvantage." 15 Yet, this glowing endorsement did not drastically increase the number of female enumerators. In

New York City, there were less than ten female enumerators for the 1880 Census. ${ }^{16}$ Therefore, it is important to keep in mind that most of the measures of female labor force participation in this study are likely low estimates. ${ }^{17}$

\section{Layout of 1880 New York City}

This study focuses on New York City, but not because it is representative of the typical American city in 1880. Scholars often write about New York City as the exemplar American metropolis, when by most measurable accounts it absolutely is the exception. In terms of size and density, truly no other American city resembled New York in 1880, which is part of the appeal of analysis, and why it has been studied time and time again. In 1880, New York City

14. Dudden, Serving Women, 74.

15. "History of Enumeration Procedure, 1790-1940," Diana Magnuson, accessed May 12, 2018, https://usa.ipums.org/usa/voliii/enumproc1.shtml.

16. Magnuson, "History of Enumeration Procedure, 1790-1940."

17. Beyond this, there is considerable debate about how female domestic servants were recorded in the 1800 Census. Enumerators were instructed to record women who kept their own homes without pay as "keeps house," in contrast to women who received wages for domestic service as "housekeepers." However, Francis Walker clearly did not trust that enumerators followed these rules correctly, because the aggregate figures published by the Census Bureau in 1880 for female labor force participation do not reflect the responses recorded by Census enumerators. There is no historical record on how or why the aggregate figures were altered from the original data, besides that the original responses would have signified a huge and unprecedented increase in female labor force participation. To account for this discrepancy, IPUMS made a logical change in their release of the individual data. All women who were recorded as "housekeepers," but were related to the head of household were changed to a nonoccupational category. While I accept their thoughtful methodological choice, I suspect that this logical change resulted in the further undercount of employed women. See: Steven Ruggles and Russell R. Menard, "Occupational Coding," Public Use Microdata Sample of the 1880 United States Census Population: User's Guide and Technical Documentation (Minneapolis: Social History Research Laboratory, 1994): 24-29 for details. 
only comprised of modern-day Manhattan. The total city population was 1.2 million. The next most populous American city was Philadelphia at about 800,000, followed by Brooklyn at about $500,000 .{ }^{18}$ On the block level, New York City was more than twice as dense as any other American city. ${ }^{19}$ New Yorkers, on average, lived on city blocks with 290 people per acre. ${ }^{20}$ In Boston, the next densest city in the country, residents lived on blocks with 144 people per acre, on average. ${ }^{21}$ This is a huge difference, considering that these cities did not have buildings more than a few stories tall, as electric elevators were not in commercial use. German-born immigrants made up 13.8 percent of New Yorkers and 18 percent of the total labor force. Irish-born immigrants made up 16.8 percent of New Yorkers and 24 percent of the total labor force. To this day, these patterns hold true. New York City is the largest, densest city in the U.S., and its economy is driven by immigrants. In 2015, 43 percent of workers in New York City were immigrants. ${ }^{22}$ This is to say that, yes, this study is about an American city, but that no other American city is comparable to New York.

18. Gergely Baics, Leah Meisterlin, and Celia Arsen, "Testing Wirth: Exploring Population Size and Density in the 19th-Century American City," Paper presented at the SSHA Conference, 2019.

19. Baics, Meisterlin, and Arsen, "Testing Wirth."

20. Ibid.

21. Ibid.

22. Thomas P. DiNapoli, and Kenneth B. Bleiwas, "The Role of Immigrants in the New York City Economy," Office of the New York State Comptroller, 2015. 
Figure 3 provides some context of the general population distribution of Manhattan in 1880 by mapping the population density of each city block. There was higher population density in lower-income neighborhoods and in more residential areas like the Lower East Side and the West Village. The Manhattan shorelines were areas where laborers lived and worked in industries along the rivers. As a result, these areas were more densely populated than the center of the island. Meanwhile, the more commercial and bourgeois parts of the city were less densely populated. Wall Street is noticeably sparse because, like today, many people worked in the Financial District, but few lived there. Likewise, population density was noticeably sparser following Broadway up to the bottom of Central Park. Also like today, these areas closer to Broadway were more commercial, hosting stores, theaters, and hotels, rather than permanent residencies. The people who lived in these areas permanently were wealthier and did not suffer from the extremely tight living conditions that infamously characterized tenement houses on the Lower East Side. Figure 3 shows that the Upper East Side was more densely populated than the Upper West side, which reflects the earlier development of the eastern side of the island. Additionally, we can see Harlem developing on the northeastern edge of the island. 
Figure 3. Population Density by Block, 1880

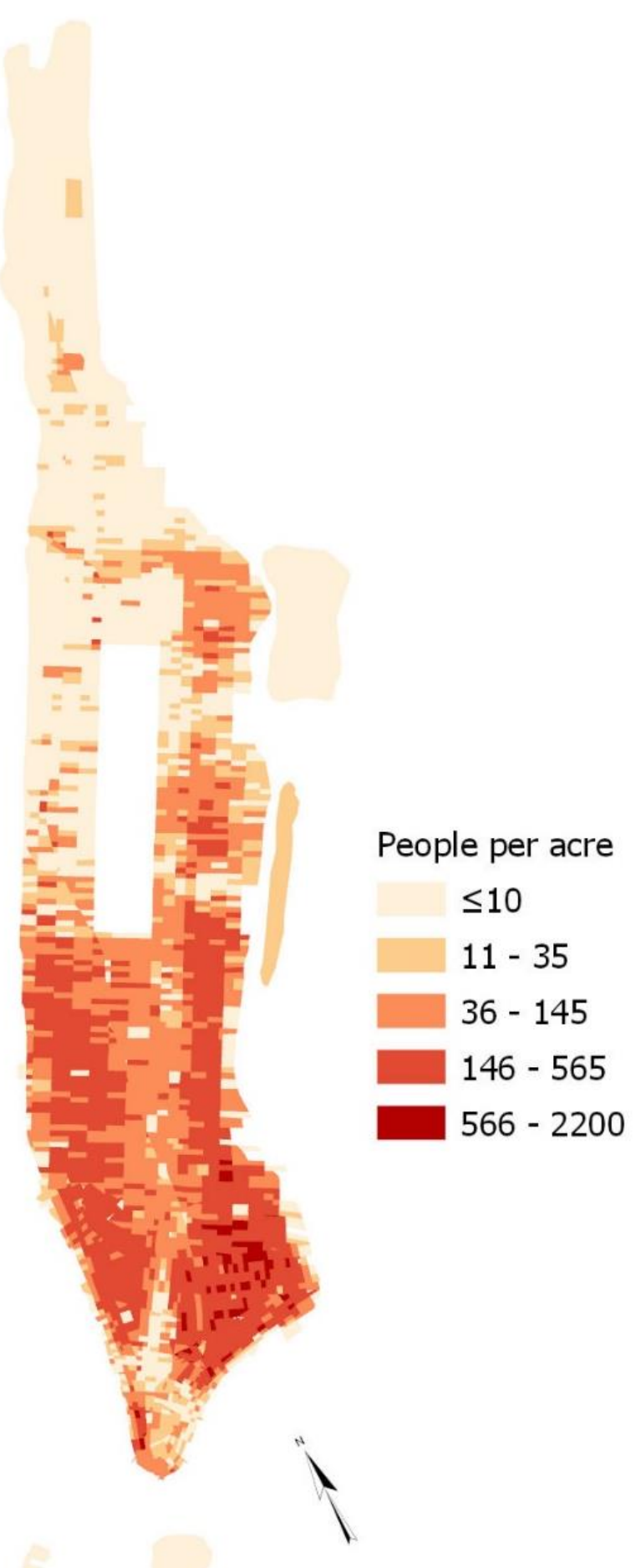

Source: Ruggles, Flood, Goeken, et. al., IPUMS USA: Version 9.0 [dataset] (Minneapolis, 2019). 
Table 1 shows the top ten most common occupations for men and women in $1880 \mathrm{New}$ York City. The two most common occupations for men were laborers and clerks in stores. "Labor" is a general category, but we assume that laborers were predominantly men in physical and manual occupations. This included day laborers who would go to docks in the morning and be contracted for a day's work. These men made up 10 percent of all male workers. The most common occupation for women was, by far, domestic service. Thirty-nine percent of working women were domestic servants. Following, with less than half the number were female milliners, dressmakers, and seamstresses. 
Table 1. Top Ten Occupations in 1880 New York City by Gender

\begin{tabular}{|c|c|c|c|c|c|}
\hline Men & Number & $\begin{array}{l}\text { Percent of } \\
\text { All } \\
\text { Employed } \\
\text { Men }\end{array}$ & Women & Number & $\begin{array}{c}\text { Percent of } \\
\text { All } \\
\text { Employed } \\
\text { Women }\end{array}$ \\
\hline Laborers (general) & 32,339 & 10 & $\begin{array}{l}\text { Domestic } \\
\text { servants }\end{array}$ & 48,127 & 39 \\
\hline Clerks in stores & 24,787 & 8 & $\begin{array}{l}\text { Milliners, } \\
\text { dressmakers, and } \\
\text { seamstresses }\end{array}$ & 21,569 & 17 \\
\hline $\begin{array}{l}\text { Draymen, hackmen, } \\
\text { teamsters }\end{array}$ & 13,846 & 4 & Laundresses & 8,257 & 7 \\
\hline Tailors & 12,511 & 4 & Tailoresses & 5,183 & 4 \\
\hline $\begin{array}{l}\text { Carpenters and } \\
\text { joiners }\end{array}$ & 9,217 & 3 & $\begin{array}{l}\text { Teachers and } \\
\text { scientific } \\
\text { persons }\end{array}$ & 2,820 & 2 \\
\hline Cigar makers & 8,040 & 3 & Saleswomen & 2,498 & 2 \\
\hline $\begin{array}{l}\text { Porters and laborers } \\
\text { in stores, warehouses }\end{array}$ & 7,469 & 2 & Cigar makers & 2,286 & 2 \\
\hline $\begin{array}{l}\text { Painters and } \\
\text { varnishers }\end{array}$ & 7,240 & 2 & $\begin{array}{l}\text { Hotel and } \\
\text { restaurant } \\
\text { employees }\end{array}$ & 2,209 & 2 \\
\hline Boot and shoemakers & 7,117 & 2 & $\begin{array}{l}\text { Artificial-flower } \\
\text { makers }\end{array}$ & 1,954 & 2 \\
\hline Butchers & 6,789 & 2 & Nurses & 1,855 & 1 \\
\hline Total & 129,355 & 41 & Total & 96,758 & 78 \\
\hline
\end{tabular}

Source: Ruggles, Flood, Goeken, et. al., IPUMS USA: Version 9.0 [dataset] (Minneapolis, 2019). 


\section{Gender-based Occupational Segregation}

Understanding which occupations were male-dominated and female-dominated, and what kinds of people participated in male or female-dominated occupations may help to understand the gendered geography of the New York City. I use a simple metric adopted from Robert Blackburn to determine whether an occupation is disproportionately male or disproportionately female. ${ }^{23}$ An occupation is considered disproportionately female if the proportion of women in that occupation is greater than the proportion of employed women overall. Likewise, an occupation is disproportionately male if the proportion of women in that occupation is less than the proportion of women in the labor force overall. Mathematically,

$$
\begin{aligned}
& F=\text { number of employed women, all occupations, } \\
& N=\text { number of employed men and women, all occupations, } \\
& F_{i}=\text { number of women employed in occupation } i, \text { and } \\
& N_{i}=\text { number of men and women employed in occupation } i .
\end{aligned}
$$

I define occupation $i$ as a disproportionately female occupation, if

$$
F_{i} / N_{i}>F / N
$$

Likewise, occupation $i$ is a disproportionately male occupation, if

$$
F_{i} / N_{i}<F / N
$$

Fifty percent would not be an appropriate threshold for defining an occupation as disproportionately male or female because women made up only 26 percent of the labor force. Based on this metric, occupations that were over 26 percent female are considered female and occupations that were less than 26 percent female are considered male. Using this metric, each of 
the 286 occupations in the IPUMS coding scheme is labeled as either disproportionately male or disproportionately female. Then, each employed resident is labeled as being in either a disproportionately male or disproportionately female occupation. A worker in a gender atypical occupation refers to a woman in a disproportionately male occupation or a man in a disproportionately female occupation.

According to this classification system, 1,426 German-born women worked in gender atypical occupations, making up just over 11 percent of the employed German-born women in the city. In comparison, 1,898 Irish-born women worked in gender-atypical occupations. Those women made up less than five percent of working Irish-born women in the city. We see that for both ethnicities, employed women most likely held occupations where a disproportionate number of the workers were female. With that said, it is interesting to note that German women were more than twice as likely as Irish women to work in gender-integrated occupations. This difference is apparent when we look at the most common occupations of German and Irish workers.

Table 2 shows the top ten occupations among German-born men and women. The top ten occupations accounted for 43 percent of all employed German-born men and 83 percent of all employed German-born women. Occupations in Table 2 highlighted in blue were disproportionately male occupations. Occupations highlighted in red were disproportionately female. We see that there was some overlap between the most common occupations for Germanborn men and women. Tailoring, a disproportionately female job, was the most common occupation for German-born men. Domestic service was the most common occupation for German-born women, but they also worked in some male-dominated occupations as cigar makers, clerks in stores, and grocery dealers. While German-born women mostly worked in 
disproportionately female occupations, they did appear to have access to work in some disproportionately male occupations, as well.

Table 2. Top Ten Occupations of German-born Immigrants in New York City, by Gender, 1880

\begin{tabular}{|c|c|c|c|c|c|}
\hline Men & Number & $\begin{array}{l}\text { Percent of All } \\
\text { German-born } \\
\text { Employed Men }\end{array}$ & Women & Number & $\begin{array}{l}\text { Percent of All } \\
\text { German-born } \\
\text { Employed } \\
\text { Women }\end{array}$ \\
\hline Tailors & 5,607 & 8 & Domestic servants & 5,955 & 47 \\
\hline Boot and shoemakers & 2,996 & 4 & $\begin{array}{c}\text { Milliners, } \\
\text { dressmakers, and } \\
\text { seamstresses }\end{array}$ & 1,644 & 13 \\
\hline Clerks in stores & 2,983 & 4 & Laundresses & 1,215 & 9 \\
\hline Butchers & 2,933 & 4 & Tailors & 939 & 7 \\
\hline Saloon keepers & 2,773 & 4 & Nurses & 193 & 2 \\
\hline Laborers (general) & 2,701 & 4 & Cigar makers & 172 & 1 \\
\hline Bakers & 2,595 & 4 & $\begin{array}{l}\text { Hotel and } \\
\text { Restaurant } \\
\text { Employees }\end{array}$ & 133 & 1 \\
\hline Cigar makers & 2,523 & 4 & Clerks in stores & 127 & 1 \\
\hline Carpenters and joiners & 2,421 & 4 & $\begin{array}{c}\text { Traders and } \\
\text { dealers in } \\
\text { groceries }\end{array}$ & 126 & 1 \\
\hline $\begin{array}{l}\text { Traders and dealers in } \\
\text { groceries }\end{array}$ & 2,157 & 3 & Midwives & 112 & 1 \\
\hline Total & 29,689 & 43 & Total & 10,616 & 83 \\
\hline
\end{tabular}

Source: Ruggles, Flood, Goeken, et. al., IPUMS USA: Version 9.0 [dataset] (Minneapolis, 2019).

Note: Red-highlighted occupations were disproportionately female and blue-highlighted occupations were disproportionately male. 
Meanwhile, Table 3 shows the top ten occupations among Irish-born men and women. The top ten occupations accounted for 57 percent of all employed Irish-born men and 90 percent of all employed Irish-born women. It is apparent from Table 3 that there was almost no overlap between the most common occupations of Irish-born men and Irish-born women. Irish-born men were most likely general laborers. The primary occupation for Irish-born women was overwhelmingly domestic service. Over 23 thousand female Irish-born immigrants were domestic servants, making up 44 percent of all domestic servants in New York City, and 58 percent of all employed Irish-born women. For both Irish-born and German-born immigrants, female workers were condensed into fewer occupations than their male counterparts. Unlike German-born women, Irish-born women appear to have had virtually no access to maledominated occupations.

Based on Table 2 and Table 3, we see that it was less likely for Irish-born men and women to work alongside one another than German-born men and women. The most common occupations of Irish-born women were all disproportionately female, whereas some of the primary occupations of German-born women were disproportionately male occupations. What impact did these differences in occupational segregation have on the geography of the city? 
Table 3. Top Ten Occupations of Irish-born Immigrants in New York City, by Gender, 1880

\begin{tabular}{|c|c|c|c|c|c|}
\hline Men & Number & $\begin{array}{l}\text { Percent of All } \\
\text { Irish-born } \\
\text { Employed Men }\end{array}$ & Women & Number & $\begin{array}{l}\text { Percent of All } \\
\text { Irish-born } \\
\text { Employed } \\
\text { Women }\end{array}$ \\
\hline Laborers (general) & 19,020 & 28 & Domestic servants & 23,012 & 58 \\
\hline $\begin{array}{c}\text { Draymen, hackmen, } \\
\text { teamsters }\end{array}$ & 4,866 & 7 & $\begin{array}{l}\text { Milliners, } \\
\text { dressmakers, and } \\
\text { seamstresses }\end{array}$ & 4,725 & 12 \\
\hline $\begin{array}{l}\text { Porters and laborers } \\
\text { in stores, warehouses }\end{array}$ & 2,811 & 4 & Laundresses & 4,214 & 11 \\
\hline Clerks in stores & 2,526 & 4 & $\begin{array}{l}\text { Hotel and } \\
\text { Restaurant } \\
\text { Employees }\end{array}$ & 1,250 & 3 \\
\hline $\begin{array}{l}\text { Carpenters and } \\
\text { joiners }\end{array}$ & 2,088 & 3 & Tailoresses & 765 & 2 \\
\hline Masons & 1,586 & 2 & Nurses & 501 & 1 \\
\hline $\begin{array}{c}\text { Boot and } \\
\text { shoemakers }\end{array}$ & 1,564 & 2 & $\begin{array}{l}\text { Shirt, cuff, and } \\
\text { collar makers }\end{array}$ & 331 & 1 \\
\hline Blacksmiths & 1,441 & 2 & $\begin{array}{l}\text { Boarding- and } \\
\text { lodging-house } \\
\text { keepers }\end{array}$ & 302 & 1 \\
\hline Tailors & 1,352 & 2 & Carpet makers & 295 & 1 \\
\hline $\begin{array}{l}\text { Painters and } \\
\text { varnishers }\end{array}$ & 1,208 & 2 & $\begin{array}{l}\text { Mill and factory } \\
\text { operatives }\end{array}$ & 293 & 1 \\
\hline Total & 38,462 & 57 & Total & 35,688 & 90 \\
\hline
\end{tabular}

Source: Ruggles, Flood, Goeken, et. al., IPUMS USA: Version 9.0 [dataset] (Minneapolis, 2019).

Note: Red-highlighted occupations were disproportionately female and blue-highlighted occupations were disproportionately male. 


\section{Spatial Implications of Gender-based Occupational Segregation}

Figure 4 maps the spatial distribution of German-born immigrants across Manhattan. To produce this map, the number of German-born people on the block is divided by the total population of the block, to get the percent German-born on the block. The color scheme shows how many standard deviations each block is away from the average of all blocks in Manhattan. The mean of New York City blocks was 12 percent German-born residents. The darker blocks are ones where German-born immigrants made up more than 12 percent of the total block population, and lighter blocks are ones where German-born immigrants made up less than 12 percent of the total block population. German-born immigrants were overrepresented in the heart of the Lower East Side where New York's infamous sweatshops and tenement homes were located. This neighborhood was home to cottage-industries, like tailoring, dress-making, and cigar-making, where manufacturing not only took place in factories, but in family homes. These industries were particularly popular among German immigrants because they functioned well with their family structure. German immigrants typically came to New York with their families, as opposed to alone. In cottage-style industries, mothers could continue to care for their families while working at home. 
Figure 4. Percent German-born Residents, by Block, 1880

Standard Deviation Units Relative to New York City Mean

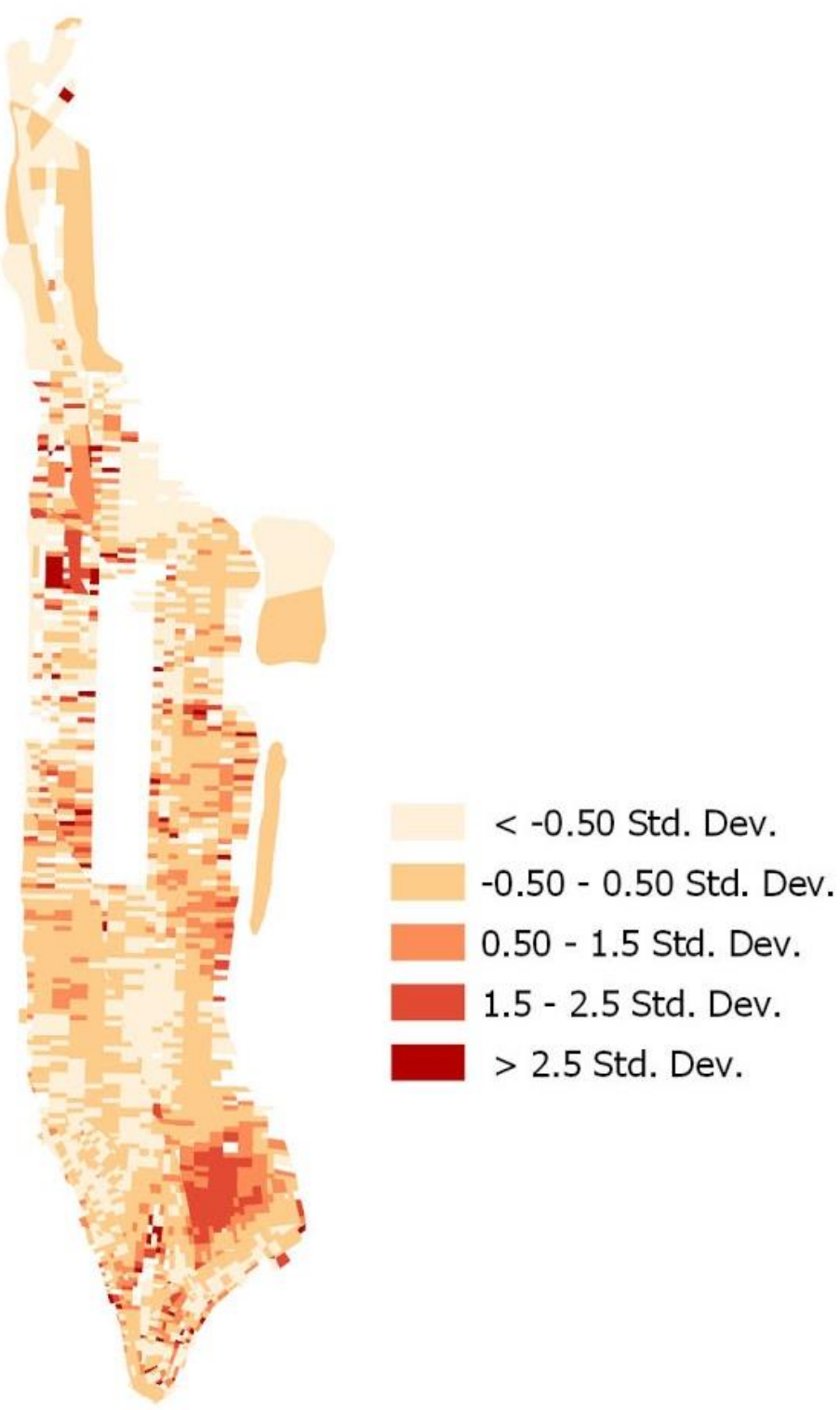

Source: Ruggles, Flood, Goeken, et. al., IPUMS USA: Version 9.0 [dataset] (Minneapolis, 2019). Note: Mean for New York City blocks is 12 percent. One standard deviation is 12 percentage points. 
Figure 5 repeats the same process as Figure 4, but with German-born women, Germanborn men, employed German-born women, and employed German-born men, using the total population of the block as the denominator in each calculation. Again, darker blocks signify an overrepresentation of the given group. The important point to note from Figure 5 is that the five maps are generally consistent with one another. This is what we would expect. Both Germanborn men and women were overrepresented on the Lower East Side. Employed Germans were generally clustered in the same parts of the city as Germans overall, just to different magnitudes. Figure 5 shows that German-born immigrants were overrepresented in the same neighborhoods, regardless of gender and labor force participation status.

Figure 6 presents the same calculations as Figure 5, but for Irish-born immigrants. What is striking about these maps is that Irish-born men and Irish-born women were not overrepresented in the same areas of the city. This is a very peculiar finding. Irish-born women were overrepresented in parts of the Lower Manhattan shoreline, and particularly in Midtown. Employed Irish-born women were exclusively overrepresented in Midtown. In contrast, Irishborn men and employed Irish-born men were overrepresented along the Hudson River and East River and underrepresented in Midtown. 


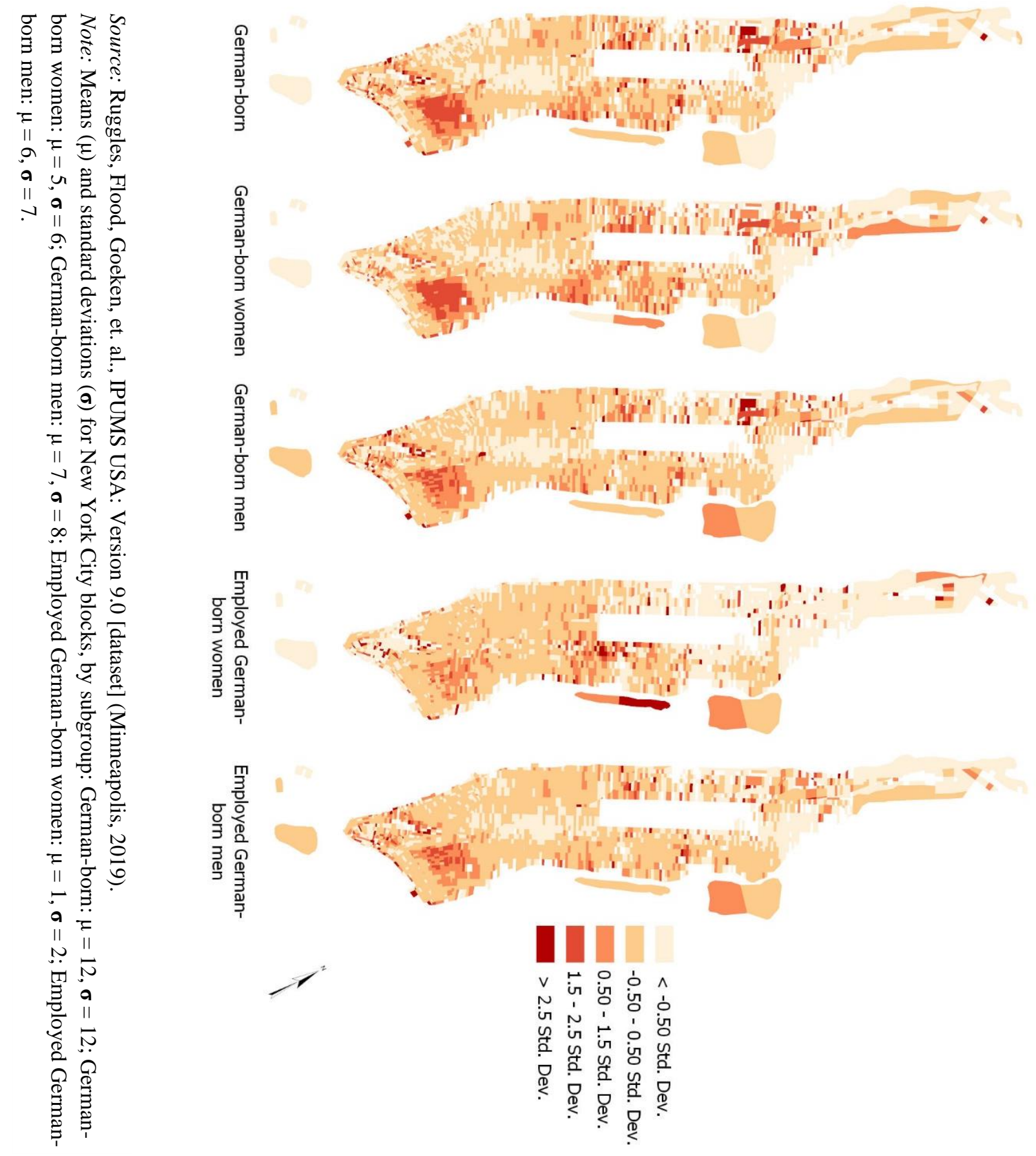




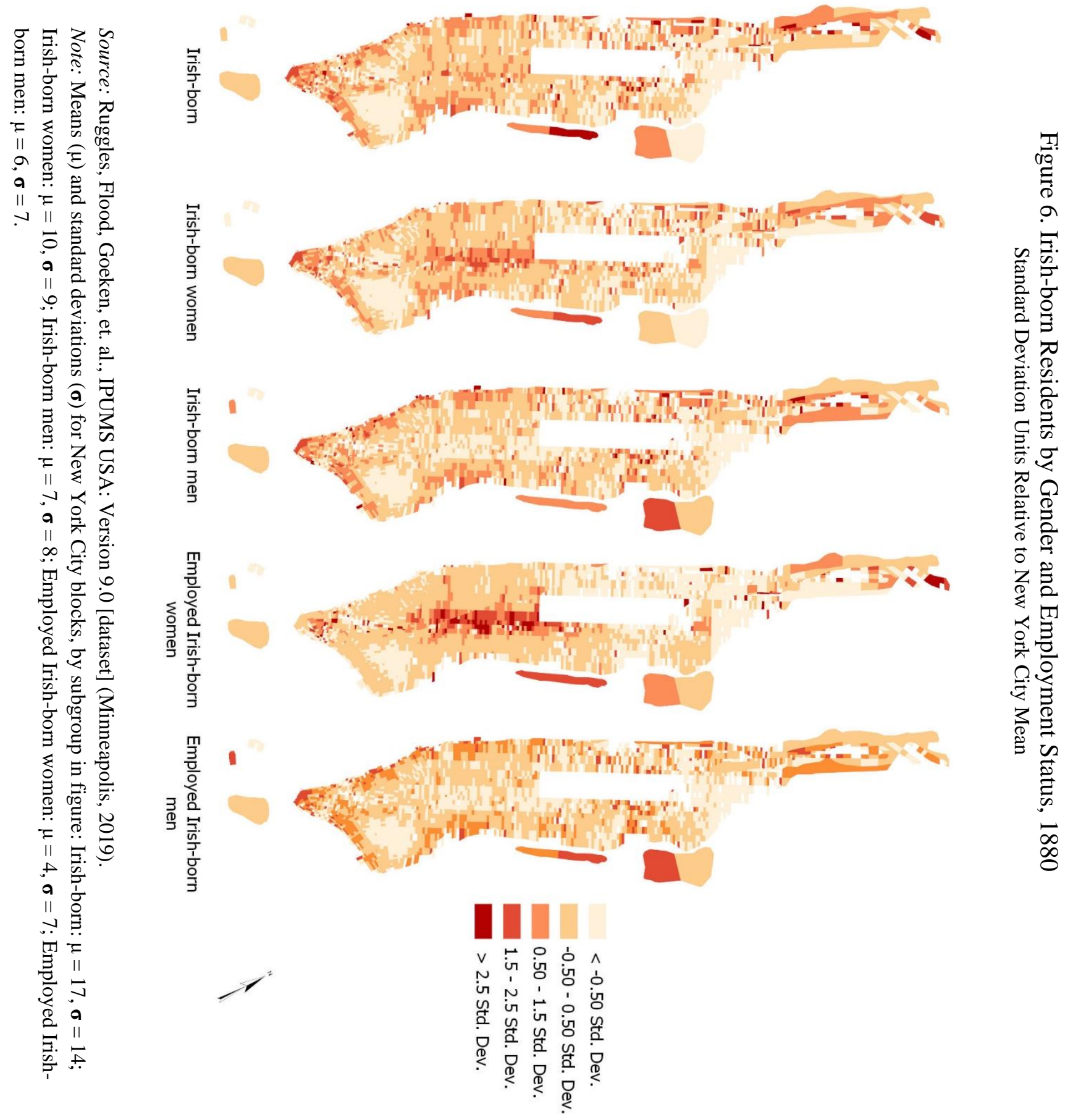


Why would Irish-born men and women live in different parts of the city? This finding is consistent with the stark occupational segregation among Irish-born workers. The disproportionate number of Irish-born women and employed Irish-born women in Midtown is consistent with our knowledge of the overwhelming presence of Irish-born women in domestic service. In Figure 6, Irish-born women stand out in Midtown because they were both lived and worked in the homes of their upper middle-class employers as live-in domestic servants. Nativeborn white employers preferred to hire Irish-born women for domestic service over women from other countries because they almost universally spoke English. The concentration of Irish-born men along the periphery of the island also makes sense when we consider their most common occupations. Irish-born men were most commonly involved in manual labor and longshoring, which would be located along the Hudson River and East River docks.

Ultimately, we can begin to understand this initially surprising spatial pattern in the context of gender-based occupational segregation. Irish-born men and women participated in occupations that had very little overlap between genders. Furthermore, those occupations were in different geographic regions of the city. Figure 6 shows the spatial implications of the severely gender-segregated labor market of Irish-born immigrants. The following section draws from these data some archetypal images of the "typical" Irish-born and German-born workers in 1880 New York City.

\section{Our Archetypes: The Irish Bridget and the German Seamstress}

From this analysis of gender-based occupational segregation and gender-based residential patterns, two key archetypes of working nineteenth century women arise: the Irish Bridget and the German seamstress. The data support the image of the typical working Irish-born woman as a 
domestic servant that lived and worked in the home of her upper-middle class employer in Midtown Manhattan. The data also show that the typical working German-born woman lived and worked on the Lower East Side, likely employed in a cottage or sweatshop industry, like dressor cigar-making. It was more likely that German-born seamstresses on the Lower East side worked nearby or in the same occupation as German-born men, whereas the Irish Bridget almost certainly did not work alongside any Irish-born men.

Why did Irish-born women tend to work in the highly gender-segregated occupation of domestic service, and why were German-born women more likely to work in cottage and sweatshop industries that were more gender-integrated? There are two primary factors. First, Irish women were more likely to migrate to the U.S. without a husband or children, and German women were more likely to migrate with their families. The ratio of women to men who immigrated to the U.S. was much higher than the ratio of women to men who immigrated to the U.S. from other European countries. By 1900, more Irish daughters than sons left Ireland. ${ }^{24}$ The majority of Irish girls could hardly pay their own fare to New York, let alone that of a whole family. Many Irish girls only arrived thanks to philanthropic gifts or through pre-paid sponsorship. ${ }^{25}$ German women, on the other hand, more often migrated with their families. The jobs in which Irish-born and German-born women worked were conducive to their respective family structures. The second reason Irish-born women were disproportionately represented in domestic service is that they came to the U.S. with high English language literacy levels, which made them more attractive to native-born white employers in New York City. This difference led to a pattern of inclusion and exclusion in domestic service.

24. Lynch-Brennan, The Irish Bridget, 42.

25. Rosalyn Baxandall and Linda Gordon, "Immigrant Women," in America's Working Women, ed. Rosalyn Baxandall and Linda Gordon (New York: W. W. Norton \& Company, 1995), 71. 


\section{Inclusion and Exclusion in Domestic Service}

Irish immigrants were favored for domestic service over other immigrant women because they almost universally spoke English. Ireland established a system of national schools in 1831 for both boys and girls ages four to eighteen. Before 1892, Irish students typically left school at the age of fourteen, but instruction was in English, leading to widespread English-language literacy in Ireland. By the end of the nineteenth century, English-language literacy was essentially universal among Irish immigrants in the U.S., and even more so for female immigrants. By the end of the nineteenth century, fewer than 39 thousand people in Ireland spoke Gaelic, in comparison with the three million Gaelic speakers in Ireland in 1800. Female domestic servants emigrated from a country that had very quickly abandoned its native language over the course of the nineteenth century. ${ }^{26}$ Even though most female Irish immigrants typically had little to no experience in domestic service, their gender seemed to be qualification enough for the job.

On the other hand, immigrant women from Continental Europe were often barred from working in American homes because they did not speak English. Although Irish women came to the U.S. with less money and practical experience than most German women, the living conditions of the typical Irish domestic servant were likely favorable to the conditions of the typical German woman living in a tenement home on the Lower East Side and working as a

seamstress. ${ }^{27}$ However, several qualitative sources suggest that German women were able to find domestic work in the homes of other wealthier German families, and other sources use

26. Lynch-Brennan, The Irish Bridget, 43-45.

27. Baxandall and Gordon, "Immigrant Women," 71. 
quantitative data to identify this pattern in other time periods. ${ }^{28}$ In her book, Women in 1900 , Christine Bose examines the 1900 U.S. Census to analyze ethnic matching between female domestic workers and their employers in the U.S. on the national level. Bose finds that German women were more likely to be hired by a German employer than an employer of any other ethnicity. In 1900, 38 percent of live-in German servants were employed in a home where the head of household was also a first- or second-generation German immigrant. Only two other racial-ethnic groups had an equally high matching rate between domestic servants and their employers. Seventy-five percent of native-born white female domestic servants lived and worked in the home of a native-born white employer. The other group with high racial-ethnic matching was Eastern European immigrants. Forty-eight percent of Eastern European female domestic servants lived and worked in the home of a first- or second-generation Eastern European immigrant employer. Bose suggests that the high ethnic matching between Eastern European immigrants and their employers was not only because of their shared language, but also because of common religion. At the time, most Eastern European immigrants were Jewish, and withingroup hiring may have been particularly important when it came to religious concerns like keeping a kosher home and kitchen. ${ }^{29}$ In contrast, Irish immigrants in 1900 were not primarily hired by other Irish families, but rather by native-born white households. Only fifteen percent of female live-in Irish domestic servants worked in the homes of first- or second-generation Irish immigrants, whereas sixty percent worked and lived in the homes of native-born white families.

In 1880 New York City, there were just under six thousand German-born women in domestic service. Were they primarily employed by other German immigrants? As previously

28. Baxandall and Gordon, "Immigrant Women," 71; Christine Bose, Women in 1900: Gateway to the Political Economy of the $20^{\text {th }}$ Century (Philadelphia: Temple University Press, 2001), 128-157.

29. Bose, Women in 1900, 142. 
presented, Figure 5 maps the geographic distribution of German-born immigrants in Manhattan. I said that, generally speaking, the spatial distribution of German-born immigrants was consistent, regardless of gender or employment status. That is, German-born men and women, employed and unemployed were overrepresented on the Lower East Side. However, there are sections of the maps that do not fall within this pattern. In particular, there is a cluster of employed Germanborn women on the east side of Central Park, approximately between $45^{\text {th }}$ and $82^{\text {nd }}$ streets, and between $6^{\text {th }}$ and $2^{\text {nd }}$ Avenues. Employed German-born women were overrepresented in this neighborhood where German-born immigrants of other groups were not overrepresented. Of the 1,612 employed German-born women who lived within this area, 76 percent of them were domestic servants. The others were launderers, schoolteachers, dress-makers and tailoresses.

Interestingly, of the German-born women in this neighborhood who were domestic servants, 66 percent were employed in a home where either the head of household or the spouse of the head of household was a first- or second-generation German immigrant. These German families on the Upper East Side had obtained middle-class jobs that afforded them the ability to hire one or more domestic servants. For example, one family that lived on the corner of Madison Avenue and $66^{\text {th }}$ Street had thirteen people living in their home at the time of the 1880 Census. The mother and father were both born in Bavaria and the father was a tobacco merchant. They had six children, two nephews, and three servants that lived with them. Two of the domestic servants were German-born and the third, the cook, was born in Ireland. A few blocks south, another family on Fifth Avenue and $50^{\text {th }}$ Street employed a German-born domestic servant. The father of the family was a shipping merchant and born in South Carolina, but his wife was born in Germany. These stories from the Census show how ethnic matching between German-born domestic servants and their employers manifested in 1880 New York City. 
In sum, German-born women typically immigrated to New York City with a spouse or with children and often worked in more gender-integrated occupations on the Lower East Side in sweatshops or cottage industries like cigar-making and tailoring. Not only did they tend towards this type of work because it better suited their family format, but because they were not welcomed as domestic servants in the homes of upper middle-class New York families due to differences in language. However, those German-born women who did come to the U.S. without a spouse or family were able to find work on the Upper East Side in the homes of upper middleclass German immigrants who had immigrated before them.

\section{Gender-Based Division of Labor Within Occupations}

So far, we discussed occupations in terms of being disproportionately male or female. We have seen that German-born women were more likely to work in gender-integrated occupations than Irish-born women. However, it is important to note that even if women were working in gender-integrated occupations, it does not mean that men and women were performing the same tasks. Some occupations were gender-integrated in the sense that both men and women worked in the same building or factory performing related tasks, but often the more specific roles were still starkly gender-segregated. Bookbinders present a relevant example of this phenomenon. Half of the bookbinders and book finishers in 1880 New York City were women, but the roles that the men and women carried out in book manufacturing were very clearly divided. Figure 7 is an engraving from the Library of Congress that depicts the gender-based division of labor in nineteenth century book manufacturing. The center frame shows men standing along the edges of the room performing the heavier manual tasks, while the women sit in the middle working at sewing machines. The figures around the frame of the engraving show men book pressing, 
cutting, and stamping. The women are shown folding and sewing. This division of labor appears quantitatively in the 1880 Census in New York City. IPUMS categorized all workers in the 1880 Census into one of 286 occupations, grouping together similar jobs. However, the specific text that Census enumerators recorded for occupation are still visible in the data. People whose occupations were recorded as "bookbinder," "paper ruler," "book folder," or "book sewer" were all grouped into the bookbinder occupational category. Eighty percent of workers who denoted their occupation as "bookbinder" and ninety-one percent of "paper rulers" were male. On the other hand, ninety-seven percent of book-folders, and ninety-nine percent of book sewers were female. ${ }^{30}$ This tells us that even within occupations, labor was still starkly divided by gender.

Figure 7. Gendered Division of Labor in Book Manufacturing

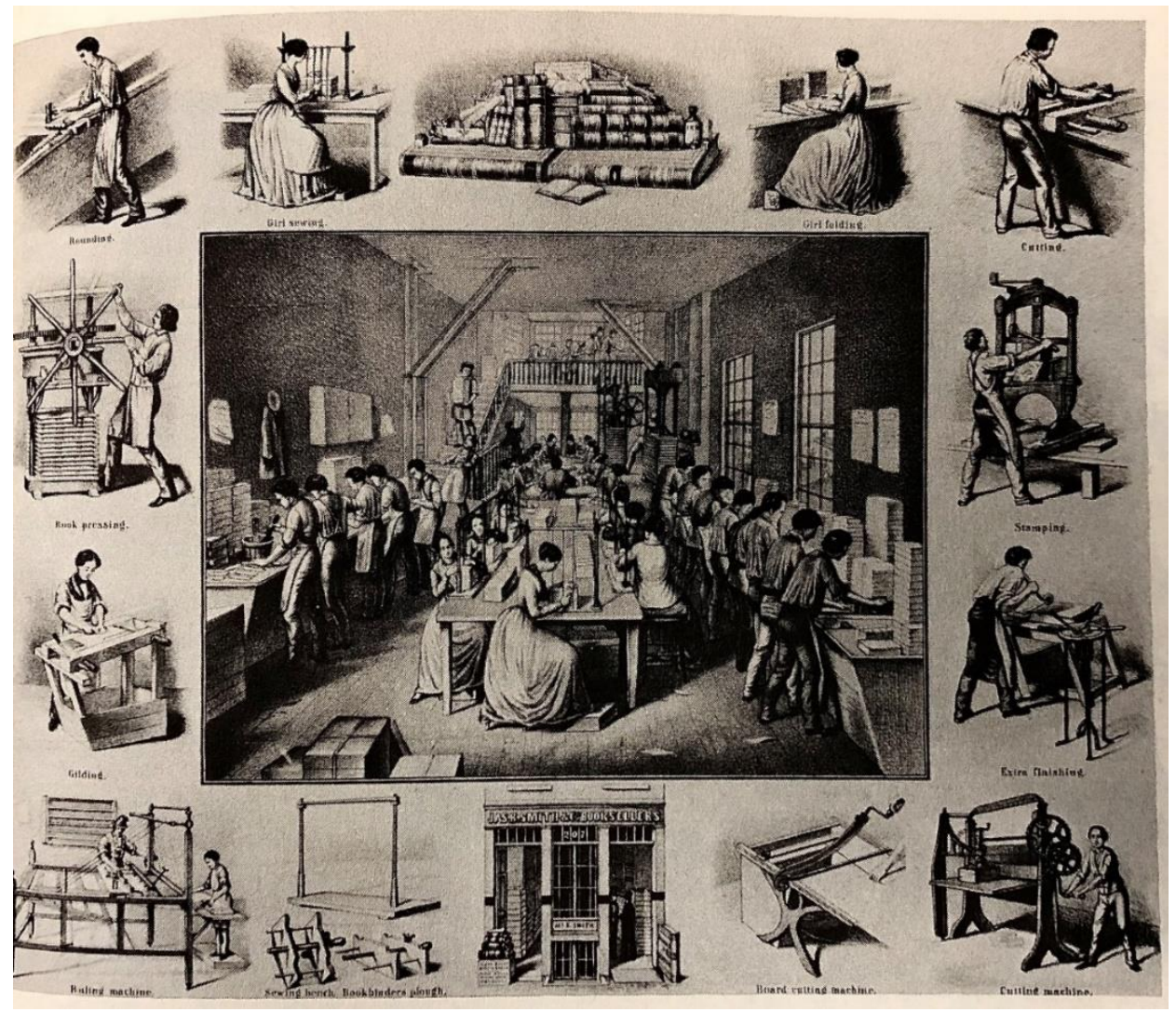

Source: Library of Congress. Rosalyn Baxandall and Linda Gordon, "A Feminist's View," in America's Working Women, ed. Rosalyn Baxandall and Linda Gordon (New York: W. W. Norton \& Company, 1995), 79.

30. There were only two men in the New York City whose occupation was recorded as "book sewer." 


\section{Summary of Part 1}

Examining the intersection of ethnicity, labor, and gender-based occupational segregation helps us understand the gendered geography of 1880 New York City. Specifically, Irish-born immigrants tended to work in occupations with higher gender-based segregation than Germanborn immigrants. This meant that working Irish-born men and women lived in different parts of the city, while working German-born immigrants tended to live in similar neighborhoods, irrespective of gender. Irish-born women were overrepresented in the highly gender-segregated occupation of domestic service because their English language skills made them preferable hires. German-born women were often barred from domestic service, but found work in the homes of first- and second-generation German immigrants on the Upper East Side. Lastly, we saw that gender-integrated occupations were still gender-segregated when observed on a more granular scale. Part 2 delves into the economic consequences of these gendered geographies and patterns of gender-based occupational segregation for working Irish-born and German-born women. Specifically, I compare the labor force participation rates of Irish-born and German-born women, and estimate the rates at which they left the labor force upon marriage and parenthood. 


\section{Part 2: The Economic Life Cycle of Women in 1880 New York City}


Together, ethnic differences in gender-based occupational segregation, English-language literacy, and demographic immigration patterns help explain the gendered geographies of Irishborn and German-born immigrants in 1880 New York City. Part 1 elaborated on this relationship between gender-based occupational segregation and gendered patterns of residential clustering. What were the social and economic consequences of this relationship - how did it impact the economic life cycle of women in these ethnic groups? When considering the economic life cycle of women, I focus on if, and/or at what age, women left the workforce, got married, and had children. I presume that women who got married mostly married men within their ethnicity, as opposed to marrying men of other ethnic groups. Fifty-eight percent of employed Irish-born women worked in domestic service. Because of their propensity to work in domestic service, employed Irish-born women were geographically segregated from the men who they would most likely marry. What impact did this have on female Irish-born labor force participation and departure from the workforce? Less than half of employed German-born women worked in domestic service. In comparison with employed Irish-born women, employed German-born women more often worked in industries that took place within their own home, or in a factory or store likely nearby home. Were German-born women more likely to remain in the workforce after getting married or having children due to their predominance in these occupations?

The nature of domestic service created a unique environment that played a pivotal role in the social and economic path of working women. It was very uncommon for female domestic servants to be married or to have children. Table 4 shows the share of employed women that were married and the share of employed women that had children, grouped by ethnicity and by employment in domestic service. Along with German-born and Irish-born women, Table 4 includes the overall employed female population, employed native-born white women, and 
employed African American women because these groups provide helpful contextual information for comparison. The category of married women only includes women who were married at the time the Census was conducted. It does not include widows or women who were separated or divorced.

Table 4. Marital and Parental Status of Employed Women, by Ethnicity

\begin{tabular}{llcc}
\hline \multirow{2}{*}{ Total } & & Percent Married & Percent Mothers \\
& & $\mathbf{1 0 . 6}$ & $\mathbf{1 2 . 1}$ \\
& Domestic Servants & 3.0 & 4.5 \\
& Not Domestic & 9.7 & 16.9 \\
Native-born White & & \\
& & $\mathbf{1 2 . 0}$ & $\mathbf{1 2 . 6}$ \\
& Domestic Servants & 7.3 & 7.7 \\
& Not Domestic & 6.9 & 14.5 \\
German-born & & & \\
& & $\mathbf{1 8 . 6}$ & $\mathbf{2 4 . 6}$ \\
& & 3.2 & 4.9 \\
Irish-born & Domestic Servants & 24.5 & 41.7 \\
& Not Domestic & $\mathbf{8 . 7}$ & $\mathbf{1 3 . 0}$ \\
& & 1.3 & 4.1 \\
& & 9.7 & 25.0 \\
African American & Domestic Servants & $\mathbf{2 4 . 9}$ & $\mathbf{1 8 . 6}$ \\
& Not Domestic & 6.6 & 8.5 \\
& & 26.6 & 31.9 \\
\hline
\end{tabular}

Source: Ruggles, Flood, Goeken, et. al., IPUMS USA: Version 9.0 [dataset] (Minneapolis, 2019).

How to Read: 8.7 percent of employed Irish-born women were married. 13.0 percent of employed Irish-born women were mothers. 1.3 percent of Irish-born women employed in domestic service were married. 9.7 percent of Irishborn women employed in an occupation besides domestic service were married, etc.

Across all ethnic groups, domestic servants were less likely to be married or to have children than the average working woman. Less than eight percent of female domestic servants, across all ethnic groups, were married. Less than nine percent of domestic servants, across all ethnic groups, had children. It was unlikely that women working in domestic service were married or had children, regardless of ethnicity. Working women were also more likely to be 
mothers than to be married, irrespective of ethnicity. While we would expect marriage and childbearing to generally coincide during this time period, the difference between married women and mothers is largely due to widowed women who worked to support their families. Seventy-nine percent of the employed women who were unmarried and had children were widows.

Overall, the marital and parental composition of employed Irish-born women resembled that of employed native-born white women and of employed women overall. However, just 1.3 percent of female Irish-born domestic servants were married, a share smaller than any of the other groups considered. It was less likely that an Irish-born domestic servant would be a mother than a domestic servant of any other ethnic group. The marital and parental composition of employed German-born women, on the other hand, did not match the compositional patterns of employed women overall. It was much more likely that an employed German-born woman was married or had children, compared to employed women in other ethnic groups. This was even more so the case for German-born women who worked outside of domestic service. Nearly a quarter of the German-born women working in occupations besides domestic service were married, and 41.7 percent were mothers. A larger share of the employed German-born women were wives and mothers than employed Irish-born women, because German-born women were more likely to be occupied in jobs in that took place within their own homes.

The only other ethnic group remotely comparable to employed German-born women's high rates of marriage and motherhood were African American women. About 26 percent of African American women who worked in non-domestic occupations were married and over 30 percent of them were mothers. Throughout this section, it will be apparent that a larger share of employed African American women were married and had children, and that African American 
women continued to participate in the labor force at higher rates than any other ethnic group after marriage and after having children. Many studies have shown that African American women have higher labor force participation rates than women of other races, regardless of marital or parental status, and researchers have several hypotheses about why this is the case. African American families had lower incomes, in part because African American men had lower educational attainment than white men, and because they faced discrimination both in hiring and in unequal wages. ${ }^{31}$ African American women worked to supplement their family's income. In general, women only had a handful of occupations available to them, but for African American women, the job market was even more limited. The top ten most common occupations among African American women accounted for 99 percent of the employed African American women, whereas the top ten occupations accounted for 77 percent of employed native-born white women, 83 percent of employed German-born women, and 90 percent of employed Irish-born women.

The composition of the female workforce by ethnicity, marital status, and parental status, shows that domestic servants were rarely married or mothers. Overall, working German-born women were more likely to be wives or mothers than their working Irish-born counterparts. It was not easy for women to remain in domestic service and continue to live in their employer's home after marriage or after having children.

31. Claudia Goldin, Understanding the Gender Gap, 27. 


\section{Labor Force Participation}

Understanding when women from different ethnic groups left the workforce can be difficult to measure without longitudinal data, but a reasonable estimate can be calculated with this cross-section from 1880. Table 5 shows the female labor force participation rate by ethnicity, age, and marital status. In addition to the labor force participation rate, Table 5 includes "percent exit," a method adopted from Claudia Goldin. ${ }^{32}$ The percent exit estimates the share of women in that group that would leave the labor force if they were married. If

$S_{L F P R}=$ labor force participation rate of the single population, and

$M_{L F P R}=$ labor force participation rate of the married population, then

Percent Exit $=\left(S_{L F P R}-M_{L F P R}\right) /\left(S_{L F P R} \times 100\right)$.

For example, 85.2 percent of single Irish-born women ages 25 to 34 , and 6.7 percent of married Irish-born women ages 25 to 34 participated in the labor force. About 92.2 percent of women ages 25 to 34 would leave the labor force if they got married because [(85.2-

6.7)/85.2]*100 is equal to 92.2 percent. A higher percent exit indicates that more women would hypothetically leave the labor force upon marriage.

32. Goldin, Understanding the Gender Gap, 16. 
Table 5. Female Labor Force Participation Rate by Age, Ethnicity, and Marital Status

\begin{tabular}{|c|c|c|c|c|c|c|c|}
\hline & & & & Age & & & \\
\hline & & $15-24$ & $25-34$ & $35-44$ & $45-54$ & $55-64$ & $65+$ \\
\hline \multirow[t]{4}{*}{ Total } & & 45.0 & 27.5 & 22.0 & 19.6 & 16.7 & 10.4 \\
\hline & Married & 7.4 & 6.7 & 7.0 & 6.1 & 5.3 & 4.0 \\
\hline & Single & 54.8 & 69.0 & 68.9 & 62.7 & 48.4 & 24.5 \\
\hline & Percent Exit* & 86.5 & 90.2 & 89.8 & 90.3 & 89.0 & 83.9 \\
\hline \multirow[t]{4}{*}{ Native-born White } & & 25.4 & 16.9 & 15.0 & 12.9 & 9.9 & 6.4 \\
\hline & Married & 5.4 & 4.3 & 4.7 & 3.6 & 3.2 & 2.2 \\
\hline & Single & 32.0 & 40.1 & 39.0 & 31.2 & 25.5 & 14.5 \\
\hline & Percent Exit* & 83.1 & 89.2 & 87.9 & 88.4 & 87.3 & 84.6 \\
\hline \multirow[t]{4}{*}{ German-born } & & 50.5 & 16.3 & 11.9 & 11.2 & 10.8 & 8.4 \\
\hline & Married & 5.7 & 4.5 & 5.4 & 4.7 & 4.4 & 3.8 \\
\hline & Single & 69.8 & 74.8 & 68.0 & 55.6 & 43.3 & 17.3 \\
\hline & Percent Exit* & 91.9 & 93.9 & 92.1 & 91.6 & 89.9 & 77.9 \\
\hline \multirow[t]{4}{*}{ Irish-born } & & 67.8 & 42.2 & 30.1 & 26.3 & 22.1 & 12.8 \\
\hline & Married & 8.3 & 6.7 & 7.0 & 6.5 & 6.3 & 5.2 \\
\hline & Single & 78.4 & 85.2 & 80.9 & 74.0 & 57.3 & 32.1 \\
\hline & Percent Exit* & 89.4 & 92.2 & 91.3 & 91.2 & 89.1 & 83.7 \\
\hline \multirow[t]{4}{*}{ African American } & & 62.0 & 57.3 & 59.0 & 63.2 & 60.3 & 38.8 \\
\hline & Married & 33.1 & 35.5 & 37.1 & 42.9 & 36.7 & 18.4 \\
\hline & Single & 72.9 & 85.0 & 87.9 & 83.1 & 88.1 & 41.7 \\
\hline & Percent Exit* & 54.6 & 58.3 & 57.8 & 48.3 & 58.3 & 55.8 \\
\hline
\end{tabular}

Source: Ruggles, Flood, Goeken, et. al., IPUMS USA: Version 9.0 [dataset] (Minneapolis, 2019).

*Percent Exit is an estimate of the share of women who left the labor force upon marriage. It is calculated by ([labor force participation rate of single population] - [labor force participation rate of married population]) / ([labor force participation of single population] $* 100$ ).

Generally, as women aged, their labor force participation rate decreased. This was true for all groups except African American women, who maintained a relatively consistent labor force participation rate until the over 65 age group. After African American women, Irish-born women had the highest overall labor force participation rates, followed by native-born white women and German-born women. Married women had much lower labor force participation rates than single women. This was true across all ethnicities, but married African American 
women had a much higher labor force participation rate compared to the other ethnic groups. In all other ethnic groups, the labor force participation rate among married women was less than 9 percent. In contrast, the labor force participation rate of married African American women was at least 30 percent for all groups under 65 years of age.

If graphed, with age groups on the $\mathrm{x}$-axis and labor force participation rates on the $\mathrm{y}$-axis, the labor force participation rates of single women would form an upside-down U-shape with the 25 to 35 age group being the maximum. Again, this was true for all groups except African American women, who maintained a high rate of labor force participation throughout all agegroups of single women. After African American women, Irish-born women had the next highest labor force participation rates for single women. Table 5 also displays the rate at which women "left" the workforce. The percent exit was similar between Irish-born women and German-born women, with 80 to 96 percent of workers in each age group leaving the workforce upon marriage. African American women were much less likely to leave the workforce if they got married, in comparison to the other ethnic groups. In all age groups, less than 60 percent of African American women left the workforce upon marriage.

To summarize, single Irish-born women had higher labor force participation rates than German-born immigrants. Besides African American women, all married women had very low labor force participation rates. Lastly, Irish-born women and German-born women left the labor force upon marriage at similar rates.

Table 6 shows female labor force participation by age and ethnicity, and parental status. Women were considered mothers if they had any children, regardless of whether the child was present or living in her home when the Census was conducted. One might expect the labor force participation rates of married women and mothers to be essentially the same. Some of the 
relationships in Table 6 do look similar to Table 5. Like married women, women with children also had very low labor force participation rates, except for African American women. However, the labor force participation rates of women without children did not follow the same patterns across ages as the labor force participation rates of single women. Unlike labor force participation rates of single women, the labor force participation rates of women without children did not take on an upside-down U-shape. For all ethnicities except African Americans, the labor force participation rate of women without children decreased as their age increased. Furthermore, Irish-born women without children were more likely to participate in the workforce than German-born women without children, across all ages. 
Table 6. Female Labor Force Participation Rate by Age, Ethnicity, and Parental Status

\begin{tabular}{|c|c|c|c|c|c|c|c|}
\hline & & & & Age & & & \\
\hline & & $15-24$ & $25-34$ & $35-44$ & $45-54$ & $55-64$ & $65+$ \\
\hline \multirow[t]{4}{*}{ Total } & & 45.0 & 27.5 & 22.0 & 19.6 & 16.7 & 10.4 \\
\hline & Mother & 5.4 & 7.0 & 10.2 & 9.7 & 7.3 & 3.5 \\
\hline & No Children & 50.4 & 50.5 & 45.9 & 41.8 & 33.5 & 19.5 \\
\hline & Percent Exit* & 89.2 & 86.1 & 77.8 & 76.8 & 78.1 & 82.1 \\
\hline \multirow{4}{*}{ Native-born White } & & 25.4 & 16.9 & 15.0 & 12.9 & 9.9 & 6.4 \\
\hline & Mother & 3.9 & 4.5 & 7.0 & 6.7 & 4.6 & 2.8 \\
\hline & No Children & 28.6 & 27.8 & 26.3 & 22.8 & 19.0 & 11.2 \\
\hline & Percent Exit* & 86.4 & 83.9 & 73.4 & 70.6 & 76.0 & 74.9 \\
\hline \multirow{4}{*}{ German-born } & & 50.5 & 16.3 & 11.9 & 11.2 & 10.8 & 8.4 \\
\hline & Mother & 3.9 & 5.3 & 7.8 & 7.9 & 6.3 & 2.8 \\
\hline & No Children & 61.1 & 42.2 & 29.5 & 25.6 & 21.7 & 16.0 \\
\hline & Percent Exit* & 93.6 & 87.4 & 73.6 & 69.0 & 71.0 & 82.3 \\
\hline \multirow[t]{4}{*}{ Irish-born } & & 67.8 & 42.2 & 30.1 & 26.3 & 22.1 & 12.8 \\
\hline & Mother & 5.0 & 7.3 & 11.4 & 10.9 & 8.2 & 3.7 \\
\hline & No Children & 73.9 & 70.2 & 61.0 & 54.5 & 43.5 & 25.2 \\
\hline & Percent Exit* & 93.2 & 89.6 & 81.3 & 80.0 & 81.0 & 85.5 \\
\hline \multirow{5}{*}{$\begin{array}{l}\text { African } \\
\text { American }\end{array}$} & & & & & & & \\
\hline & & 62.0 & 57.3 & 59.0 & 63.2 & 60.3 & 38.8 \\
\hline & Mother & 24.0 & 33.4 & 43.6 & 49.9 & 42.5 & 23.2 \\
\hline & No Children & 67.8 & 68.1 & 68.7 & 72.2 & 71.3 & 48.1 \\
\hline & Percent Exit* & 64.6 & 50.9 & 36.6 & 30.9 & 40.3 & 51.8 \\
\hline
\end{tabular}

Source: Ruggles, Flood, Goeken, et. al., IPUMS USA: Version 9.0 [dataset] (Minneapolis, 2019).

*Percent Exit is an estimate of the share of women who left the labor force upon marriage. It is calculated by ([labor force participation rate of single population with no children] - [labor force participation rate of married population]) / ([labor force participation of population with no children] $* 100)$.

The most interesting point to note from the percent exit measure in Table 6 is that Irishborn women were more likely than German-born women to leave the labor force upon having a child, regardless of the age of the woman. This is makes sense considering that German-born women were more likely to be employed in cottage industries than their Irish-born counterparts. German-born women more often continued to work after getting married or having children 
because they could continue to take care of domestic tasks, including child rearing while working from their home. Table 2, from Part 1, which shows the share of employed Germanborn women in their most common occupations, also shows that milliners, dressmakers, seamstresses, tailors, and cigar-makers collectively made up 21 percent of employed Germanborn women. Women in these occupations would most likely conduct work in piecework from home. In comparison, these occupations made of 15 percent of the employed Irish-born women. Thirty-one percent of employed German-born mothers worked in one of these occupations. That is, over a third of the German-born women who continued to work after having children were working in just a handful of occupations that were almost exclusively conducted from their own homes.

In summary, Irish-born women without children were more likely to remain in the labor force as they aged compared to German-born women without children. However, Irish-born women were more likely to leave the workforce when they had children than German-born women, and this was the case across all age groups. It makes sense that Irish-born women left the workforce at higher rates than German-born women when they had children. First, because Irish-born women were typically in lower-wage jobs than German-born women, they had a lower opportunity cost when exiting the workforce. In New York in 1870, seamstresses in families earned $\$ 7$ to $\$ 12$ a week, whereas domestic servants earned $\$ 2$ to $\$ 3.50$ a week plus board. ${ }^{33}$ Second, when Irish-born women married or had children, they often relocated to neighborhoods where Irish men lived — neighborhoods that did not have labor markets that matched their existing skills. Figure 8 illustrates the movement of Irish-born women from Midtown to 
neighborhoods where Irish-born men already lived. Figure 8 consists of five maps, each visualizing the percent of the block population that was made up of a group of Irish-born immigrants. The first map shows married Irish-born women, the second shows Irish-born mothers, the third shows Irish-born women, excluding domestic servants, the fourth shows Irishborn men, and the fifth shows employed Irish-born women.

It is striking that married Irish-born women and Irish-born women with children almost exactly followed the residential patterns of Irish-born men. Like Irish-born men, married Irishborn women were overrepresented along the Manhattan shoreline, both on the Lower East and Lower West side. Both maps are the inverse of the employed Irish-born women map. Figure 8 shows that the visible overrepresentation of Irish-born women in Midtown is explained by the presence of domestic servants, because after removing domestic servants and mapping the remaining Irish-born women, the resulting map follows the block-level patterns of Irish-born men. 


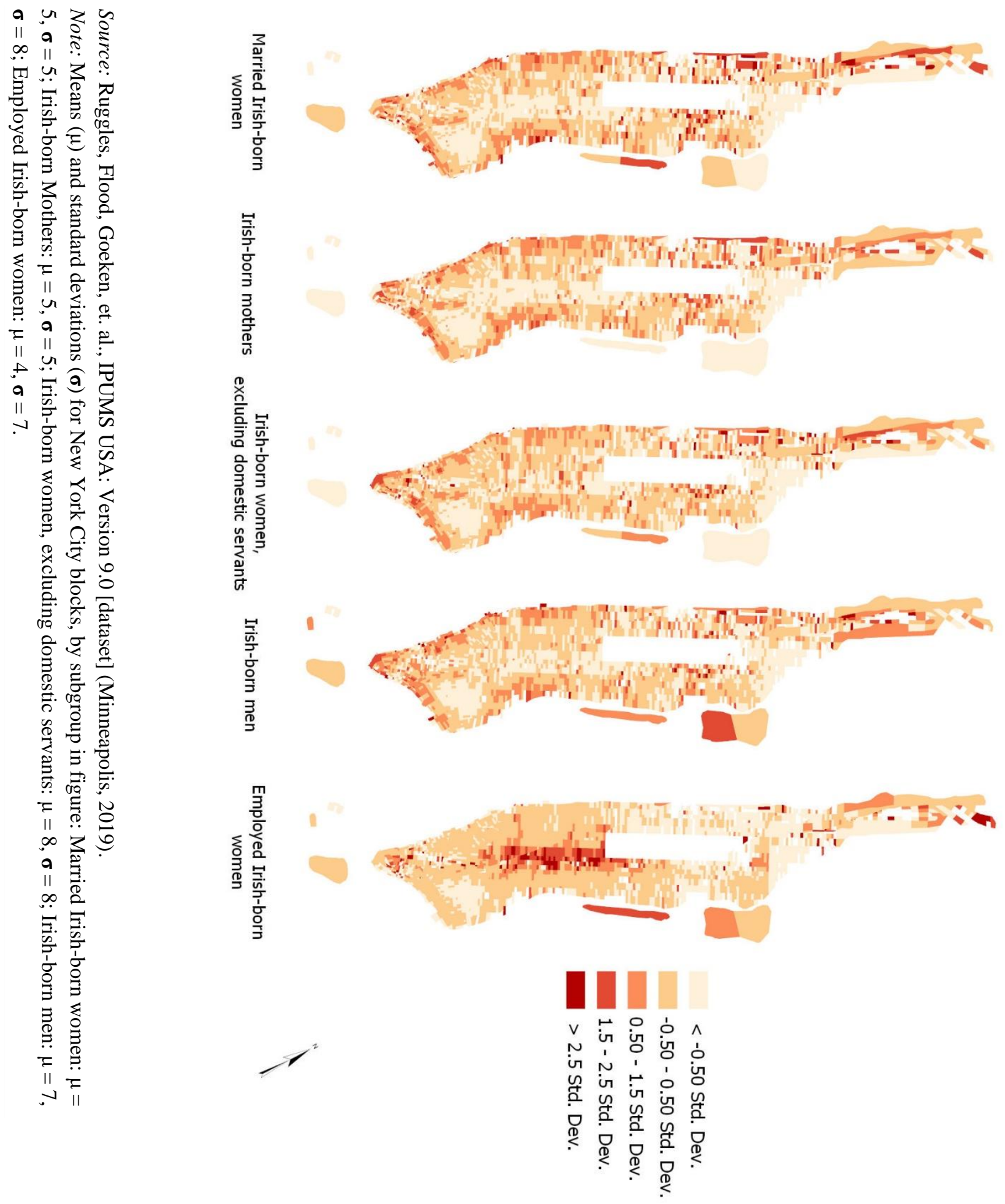

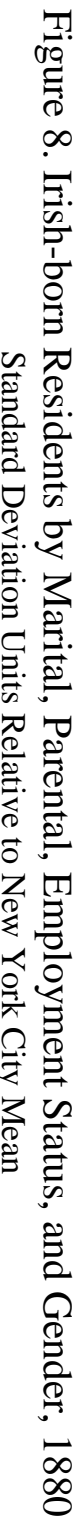




\section{Conclusion}

Geographic residential patterns affected important events in the economic life cycle of first-generation immigrant women in 1880 New York City. Irish-born women were more likely than German-born women to leave the workforce after having a child, at least in part because of where they lived. Irish-born men and women were overrepresented in different parts of New York City, and investigating gender-based occupational segregation help explain this surprising spatial pattern. Ethnic differences in literacy levels and demographic immigration patterns help explain why Irish-born immigrants were more likely than German-born immigrants to work in highly gender-segregated occupations, especially domestic service. Geocoded residential addresses along with individual level Census data allow for a thorough and granular spatial analysis that is attuned to differences within and between ethnic groups. Ultimately, this thesis presents some methods for understanding the relationships between gender, labor, and geography in a nineteenth century American city. 


\section{Bibliography}

Baics, Gergely, Leah Meisterlin, and Celia Arsen. "Testing Wirth: Exploring Population Size and Density in the 19th-Century American City." Paper presented at The SSHA Meeting, Chicago, November, 2019.

Baxandall, Rosalyn and Linda Gordon, ed. America's Working Women: A Documentary History 1600 to the Present, edited by Rosalyn Baxandall and Linda Gordon, 78-93. New York: W.W. Norton \& Company, 1995.

Blackburn, Robert M. "The Measurement of Occupational Segregation and Its Component Dimensions." International Journal of Social Research Methodology 15, no. 3 (May 1, 2012): 175-98.

Blumen, Orna. "Gender Differences in the Journey to Work.” Urban Geography 15, no. 3 (April 1, 1994): 223-45.

Bose, Christine. Women in 1900: Gateway to the Political Economy of the 20th Century. Philadelphia: Temple University Press, 2001.

Cantor, Milton, and Bruce Laurie. Class, Sex, and the Woman Worker. Greenwood Press, 1977.

DiNapoli, Thomas P., and Kenneth B. Bleiwas. "The Role of Immigrants in the New York City Economy." Office of the New York State Comptroller, November 2015.

https://osc.state.ny.us/osdc/rpt7-2016.pdf.

Dudden, Faye. Serving Women: Household Service in Nineteenth-Century America. Middletown, CT: Wesleyan University Press, 1983.

Fernandez, Roberto M., and Celina Su. "Space in the Study of Labor Markets." Annual Review of Sociology 30, no. 1 (August 1, 2004): 545-69.

Friedan, Betty. The Feminine Mystique. New York: W. W. Norton \& Company, 1963.

Goldin, Claudia. Understanding the Gender Gap: An Economic History of American Women. New York: Oxford University Press, 1990.

Hanson, Susan, and Geraldine Pratt. Gender, Work, and Space. Routledge, 1995.

Katzman, David. Seven Days a Week: Women and Domestic Service in Industrializing America. New York: Oxford University Press, 1978. 
Kwan, Mei-Po. "Feminist Visualization: Re-Envisioning GIS as a Method in Feminist Geographic Research." Annals of the Association of American Geographers. Association of American Geographers 92, no. 4 (December 1, 2002): 645-61.

Logan, John. R., Jason Jindrich, Hyoungjin Shin, and Weiwei Zhang. "Mapping America in 1880: The Urban Transition Historical GIS Project." Historical Methods 44 no. 1 (February 2011): 49-60. https://doi.org/10.1080/01615440.2010.517509.

Lynch-Brennan, Margaret E. The Irish Bridget: Irish Immigrant Women in Domestic Service in America, 1840-1930. Syracuse, New York: Syracuse University Press, 2014.

Madden, Janice. "Why Women Work Closer to Home.” Urban Studies 18, no. 2 (June 1, 1981): 181-94.

Magnuson, Diana L. "History of Enumeration Procedures, 1790-1940." In History of the Census and its Samples. Accessed December 2, 2019. https://usa.ipums.org/usa/voliii/enumproc1.shtml.

Neill, Charles Patrick. Summary of the Report on Condition of Woman and Child Wage Earners in the United States. U.S. Government Printing Office, 1916.

Olson, Sherry. "Re-Focus on Women in an Industrial Revolution.” In The Routledge Companion to Spatial History, edited by Ian Gregory, Don DeBats, and Don Lafreniere, 1st ed., 1234. Milton Park, Abingdon, Oxon; New York, NY: Routledge, 2018.

Rowbotham, Sheila. Hidden from History: Rediscovering Women in History from the 17th Century to the Present. New York: Random House, 1975.

Ruggles, Steven, Sarah Flood, Ronald Goeken, Josiah Grover, Erin Meyer, Jose Pacas and Matthew Sobek. IPUMS USA: Version 9.0 [dataset]. Minneapolis, 2019. https://doi.org/10.18128/D010.V9.0.

Ruggles, Steven and Russell R. Menard. "Occupational Coding." Public Use Microdata Sample of the 1880 United States Census Population: User's Guide and Technical Documentation. Minneapolis: Social History Research Laboratory, 1994, 24-29.

Stansell, Christine. City of Women: Sex and Class in New York, 1789-1860. University of Illinois Press, 1987.

United States Census Bureau. "Pop Culture: 1880." In Fast Facts Through the Decades. Accessed May 15, 2018 from: https://www.census.gov/history/www/through_the_decades/fast_facts/1880_fast_facts.ht $\mathrm{ml}$. 
Weatherford, Doris. Foreign and Female: Immigrant Women in America, 1840-1930. Schocken Books, 1986.

White, Michelle J. "Sex Differences in Urban Commuting Patterns." The American Economic Review 76, no. 2 (1986): 368-72. 